\title{
Monomeric Germanium(II) Amides Bearing $\beta$-Diketiminato Ligands: Synthesis, Structural Characterization, and Thermal Properties
}

\author{
Ernesto Ballestero-Martínez, ${ }^{[a]}$ Jerzy Klosin, ${ }^{[b]}$ \\ Bradley D. Fahlman, ${ }^{*[c]}$ and Leslie W. Pineda ${ }^{*[a]}$
}

Keywords: Germanium / N ligands / Amides / Metathesis / Structure elucidation

Germanium(II) compounds featuring $\beta$-diketiminate-type ligands are attractive for applications as nanoparticle precursors, imaging agents, and components of electronic devices. In this work, we report the synthesis of $\beta$-diketiminatogermanium(II) amides L'Ge(NHPh) [1, L' $=\{\mathrm{HC}(\mathrm{CMeN}-2,4,6$ $\left.\left.\left.\mathrm{Me}_{3} \mathrm{C}_{6} \mathrm{H}_{2}\right)_{2}\right\}^{-}\right]$, L'Ge(4-NHPy) (2), L'Ge(2-NHPy) (3), and LGe(2-NHPy) (4), L = $\left.\left\{\mathrm{HC}\left(\mathrm{CMeN}-2,6-i \mathrm{Pr}_{2} \mathrm{C}_{6} \mathrm{H}_{3}\right)_{2}\right\}^{-}\right]$, which were obtained by the reaction of a low-valent organogermanium halide ( $\mathrm{L}^{\prime} \mathrm{GeCl}$ or $\mathrm{LGeCl}$ ) with a lithium salt of the respective aromatic amine $(\mathrm{LiNHPh})$ or aminopyridine [Li(4-
NHPy) and Li(2-NHPy)]. Compounds 1-4 were characterized with several techniques such as melting point, FTIR, ${ }^{1} \mathrm{H}$ and ${ }^{13} \mathrm{C}$ NMR spectroscopy, elemental analysis, X-ray diffraction, and thermogravimetric analysis (TGA). Compounds 1-3 and 4 crystallized in the orthorhombic (space group Pnma) and monoclinic (space group $P 2_{1} / C$ ) crystal systems, respectively. In all cases, the geometry around the central germanium atom was highly tetrahedrally distorted. According to TGA data, 1-4 do not sublime intact but rather exhibit thermal decomposition.

\section{Introduction}

Germylenes are low-valent species with a lone electron pair and acid-base behavior that is reminiscent of the carbon(II) atom localized in carbenes. ${ }^{[1]}$ As opposed to carbenes, several neutral germylenes have been isolated and characterized that feature functional groups such as chloride, $^{[2]}$ fluoride, ${ }^{[3]}$ hydroxide, ${ }^{[4]}$ hydride, ${ }^{[3,5]}$ amide, ${ }^{6]}$ and azide. ${ }^{[7]}$ In this regard, the utilization of monoanionic and bidentate $\beta$-diketiminato ligands $\{\mathrm{L}, \mathrm{L}=[\mathrm{HC}(\mathrm{CMeN}-2,6-$ $\left.\left.i \mathrm{Pr}_{2} \mathrm{C}_{6} \mathrm{H}_{3}\right)_{2}\right]^{-}$; Scheme 1$\}^{[2-7]}$ provides electronic and steric characteristics that allow the chemical stabilization of highly reactive moieties. ${ }^{[8]}$ These low-valent germanium compounds are also used as versatile precursors toward novel chemical compounds. ${ }^{[1]}$ In our case, we are interested in germylene amides bearing $\beta$-diketiminato ligands.

Previous reports disclosed the preparation of $\operatorname{LGeNH}\left(2,6-i \mathrm{Pr}_{2} \mathrm{C}_{6} \mathrm{H}_{3}\right)^{[9]}$ and $\mathrm{L}^{*} \mathrm{GeNH}\left(2,6-i \mathrm{Pr}_{2} \mathrm{C}_{6} \mathrm{H}_{3}\right)^{[10]}$ (Scheme 1 for $\mathrm{L}^{*}$ ) amides, which were obtained unexpec-

[a] Centro de Electroquímica y Energía Química (CELEQ) and Escuela de Química, Universidad de Costa Rica, 2060 San José, Costa Rica E-mail: leslie.pineda@ucr.ac.cr http://celeq.ucr.ac.cr

[b] Corporate R\&D, The Dow Chemical Company, Midland, MI 48674, USA

[c] Department of Chemistry and Science of Advanced Materials Program, Central Michigan University, Mount Pleasant, MI 48859, USA

E-mail: fahlm1b@cmich.edu https://www.cmich.edu tedly in modest yields following the reduction of $\mathrm{LGeCl}^{[9]}$ or $\mathrm{L}^{*} \mathrm{GeCl}^{[10]}$ with alkaline reducing agents and subsequent ligand rearrangement. The reaction of $\mathrm{L}^{x} \mathrm{Ge}$ germylene with ammonia ${ }^{[6]}$ or $\mathrm{HN}\left(\mathrm{C}_{6} \mathrm{~F}_{5}\right)_{2}{ }^{[11]}$ in nonpolar organic solvents afforded $\mathrm{LGeNH}_{2}{ }^{[6]}$ and $\mathrm{LGeN}\left(\mathrm{C}_{6} \mathrm{~F}_{5}\right)_{2},{ }^{[11]}$ respectively (Scheme 1). Use of sterically encumbered lithium amine salts with an organogermanium(II) halide led to metathesis products $\mathrm{LGeNMe}_{2}{ }^{[12]}$ and $\operatorname{LGeNH}(2,6-$ $\left.i \operatorname{Pr}_{2} \mathrm{C}_{6} \mathrm{H}_{3}\right)^{[13]}$ and ligand intramolecular $\mathrm{C}-\mathrm{H}$ activation to form $\mathrm{L}^{x} \mathrm{Ge}^{[13,14]}$ depending on the identity of the salt (Scheme 2). It should be noted that the amide nitrogen atom in the former compounds bears two methyl group substituents that act as electron-density donors, and a 2,6$i \mathrm{Pr}_{2} \mathrm{C}_{6} \mathrm{H}_{3}$ substituent that behaves like an electron-density acceptor. However, in the latter example, relatively larger $\left(\mathrm{SiMe}_{3}\right)_{2}, \mathrm{Et}_{2}$, and $i \mathrm{Pr}_{2}$ substituents favor donation of electron density. ${ }^{[15]}$

Conversely, $\mathrm{L}^{\prime \prime} \mathrm{GeCl}$ (see Scheme 1 for $\mathrm{L}^{\prime \prime}$ ) readily reacts with $\mathrm{LiN}\left(\mathrm{SiMe}_{3}\right)_{2}$ to give $\mathrm{L}^{\prime \prime} \mathrm{GeN}\left(\mathrm{SiMe}_{3}\right)_{2}$ product. [16] These examples clearly demonstrate how easily the chemical composition of the product can be changed by fine-tuning the steric or electronic features of the ligands employed in the germanium(II) or lithium amide precursors.

Germylene amides are not only of interest for purely synthetic or mechanistic pursuits, they also exhibit chemical functionalities that are relevant for Ge-based nanomaterials, electronic devices, ${ }^{[17]}$ co-sensitizers in dye-sensitized solar cells, ${ }^{[18]}$ and as biological markers. ${ }^{[19]}$ In this context, a variety of synthetic approaches have emerged related to 


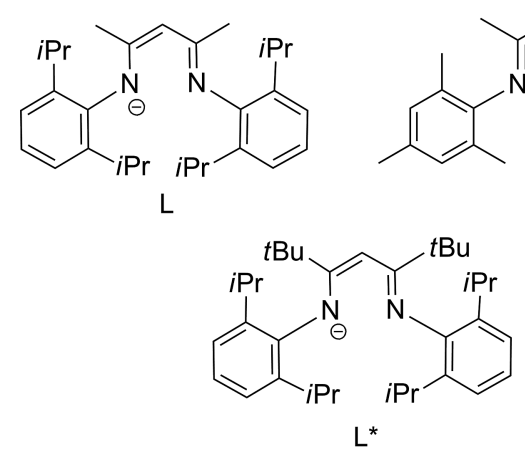<smiles>CC(/C=C(/C)Nc1ccccc1)=Nc1ccccc1</smiles>

L"

Scheme 1. Structure of some $\beta$-diketiminato ligands.

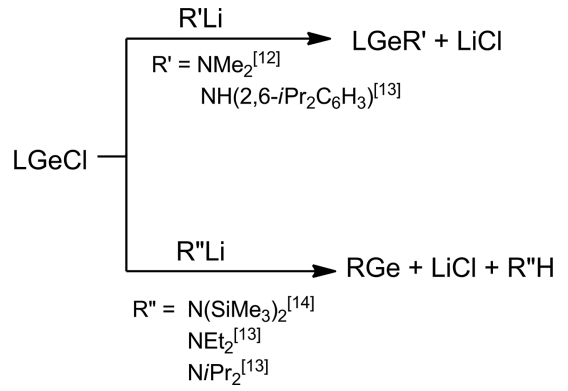

Scheme 2. Reactivity of $\mathrm{LGeCl}$ with some $\mathrm{Li}$ amides.

germanium nanoparticle growth (e.g., high and mild temperatures, high pressures, and seed catalysts). ${ }^{[17]}$

For thin-film growth applications, $\beta$-diketiminato ligands are widely reported to enhance the thermal stability of molecular compounds. ${ }^{[20]}$ For example, $\beta$-diketiminato zirconium(VI) complexes were utilized as versatile precursors for the chemical vapor deposition (CVD) of Zr-based materials. ${ }^{[21]}$ Previously, we have studied the structures and volatilities of $\beta$-ketoiminato hafnium(IV) precursors for the growth of $\mathrm{HfO}_{2}$ thin films. ${ }^{[22]}$ Herein we report the synthesis and characterization of germanium(II) analogues. Our interest in this system is based on the ability of $\beta$-diketiminato ligands to stabilize germanium compounds in low oxidation states and low coordination numbers, and the dearth of germanium(II)-based CVD precursors, which should lead to interesting synthetic strategies for advanced materials.

The amines selected for this current study include aniline $\left(\mathrm{H}_{2} \mathrm{NPh}\right.$, b.p. $\left.184.17^{\circ} \mathrm{C}\right)$, 2-aminopyridine $\left(2-\mathrm{H}_{2} \mathrm{NPy}\right.$, b.p. $\left.210{ }^{\circ} \mathrm{C}\right)$, and 4-aminopyridine $\left(4-\mathrm{H}_{2} \mathrm{NPy}\right.$, b.p. $\left.273^{\circ} \mathrm{C}\right)$. Our rationale for choosing these amines are twofold: first, both exhibit a relatively low vaporization temperature that is desirable for CVD applications; second, the aminopyridines have both a primary amine and a pyridine moiety that can be used as an additional coordination site. Herein, we report the syntheses, X-ray structural characterization, and thermogravimetric analyses (TGA) of $\mathrm{L}^{\prime} \mathrm{Ge}(\mathrm{NHPh})\left\{\mathbf{1}, \mathrm{L}^{\prime}\right.$ $=\left[\mathrm{HC}\left(\mathrm{CMeN}-2,4,6-\mathrm{Me}_{3} \mathrm{C}_{6} \mathrm{H}_{2}\right)_{2}\right]^{-}, \quad$ Scheme 1\}; L'Ge(4NHPy) (2), L'Ge(2-NHPy) (3); and LGe(2-NHPy) \{4, L $\left.=\left[\mathrm{HC}\left(\mathrm{CMeN}-2,6-i \mathrm{Pr}_{2} \mathrm{C}_{6} \mathrm{H}_{3}\right)_{2}\right]^{-}\right\}$, accomplished by reacting $\mathrm{L}^{\prime} \mathrm{GeCl}$ or $\mathrm{LGeCl}$ and the lithium salt of the corresponding aromatic amine (LiNHPh) or aminopyridine [ $\mathrm{Li}(2-\mathrm{NHPy})$ and $\operatorname{Li}(4-\mathrm{NHPy})]$. Compound $\mathbf{4}$ was prepared to determine the steric effect of the ligand relative to 1-3. Additionally, we report the FTIR and ${ }^{1} \mathrm{H} /{ }^{13} \mathrm{C}$ NMR spectroscopy, thermal stabilities, and elemental analyses for 1-4.

\section{Results and Discussion}

Lithium salt amides were prepared by mixing an equivalent amount of amine and alkyllithium salt in THF at $-78^{\circ} \mathrm{C}$ with concomitant methane evolution as a byproduct, then used in situ because of their high reactivity and instability. ${ }^{[23]}$ In the case of LiNHPh and Li(2-NHPy), a clear solution was obtained, whereas for $4-\mathrm{NH}_{2} \mathrm{Py}$, the resultant lithium salt was a white suspension. The metathesis reaction of lithium amide in the presence of $\mathrm{L}^{\prime} \mathrm{GeCl}$ or $\mathrm{LGeCl}$ in THF furnished a pale yellow solution for $\mathbf{1}, \mathbf{3}$, and $\mathbf{4}$, whereas the reaction mixture to make 2 changed from green to a yellow solution after stirring $5 \mathrm{~h}$ from $-78^{\circ} \mathrm{C}$ to ambient temperature (Scheme 3 ).

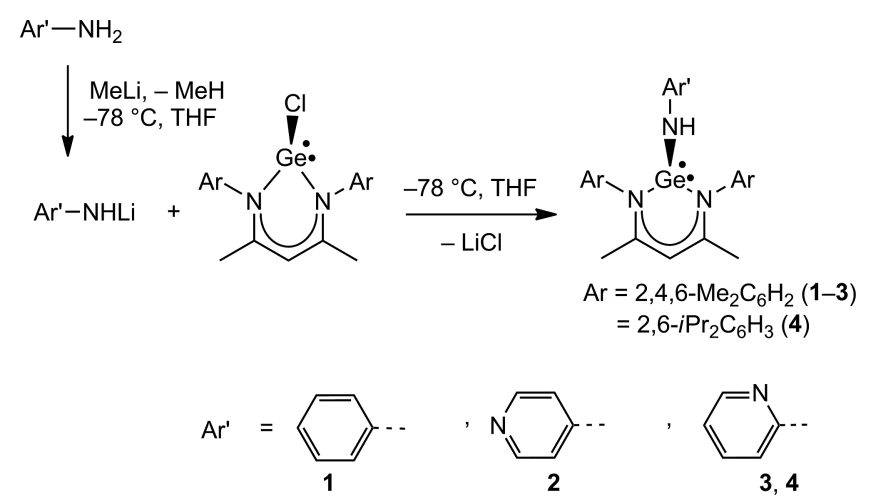

Scheme 3. Synthesis of $\mathbf{1}-\mathbf{4}$.

Compounds 1-4 are pale yellow microcrystalline solids soluble in THF, toluene, and benzene, 1-3 are insoluble in hexane, but $\mathbf{4}$ solubilizes only slightly. Compounds $1-3$ have melting points above $200{ }^{\circ} \mathrm{C}$, and 4 melts at about $168^{\circ} \mathrm{C}$. In the FTIR spectra of $\mathbf{1 - 4}, \mathbf{N}-\mathrm{H}$ stretching bands appear at $3377,3321,3365$, and $3348 \mathrm{~cm}^{-1}$, respectively, and are comparable to the $\mathrm{N}-\mathrm{H}$ group of $\mathrm{LGeNH}_{2}\left(3333 \mathrm{~cm}^{-1}\right)^{[6]}$ and $\mathrm{LGa}\left(\mathrm{NH}_{2}\right)_{2}\left(3359 \mathrm{~cm}^{-1}\right),{ }^{[24]}$ and the $\mathrm{N}-\mathrm{H}$ vibrations observed for $\mathrm{LGa}(\mathrm{NHEt})_{2}, \mathrm{LGa}(\mathrm{NH} i \mathrm{Pr})_{2}, \mathrm{LGa}(\mathrm{NH} n \mathrm{Bu})_{2}$, $\mathrm{LGa}(\mathrm{NHPh})_{2}$, and $\mathrm{LAl}(\mathrm{NHEt})_{2}\left(3371-3381 \mathrm{~cm}^{-1}\right) \cdot{ }^{[23 \mathrm{~d}]}$ For 
1-4, the ${ }^{1} \mathrm{H}$ NMR spectra exhibit broad signals $(\delta=$ $5.00 \mathrm{ppm}$ for $\mathbf{1}, 5.08 \mathrm{ppm}$ for $\mathbf{2}, 6.13 \mathrm{ppm}$ for $\mathbf{3}$, and $6.06 \mathrm{ppm}$ for 4), which can be assigned to the $\mathrm{N}-\mathrm{H}$ proton. Interestingly, the position of the $\mathrm{N}_{\text {endo }}$ atom in the pyridine ring relative to the amide $\mathrm{N}-\mathrm{H}$ bond for $\mathbf{2}$ and $\mathbf{3}$ brings about a larger chemical shift. This is likely due to more pronounced deshielding caused by interactions between the lone electron pair on the pyridinic nitrogen atom and the $\pi$-electron system of the aromatic ring with an $\mathrm{N}-\mathrm{H}$ fragment. Such electronic interactions are not present in the aniline molecule of $\mathbf{1}$, which gives rise to a smaller chemical shift relative to $\mathbf{2}$ and $\mathbf{3}$. By comparison, the $\mathrm{N}-\mathrm{H}$ bond chemical shift in $\mathbf{4}$ is smaller than that of $\mathbf{3}$, which is likely due to bulky isopropyl groups on the aromatic rings. These chemical shifts are in good agreement with previously reported $\mathrm{N}-\mathrm{H}$ signals for $\operatorname{LGeNH}\left(2,6-i \operatorname{Pr}_{2} \mathrm{C}_{6} \mathrm{H}_{3}\right) \quad(\delta=$ $5.64 \mathrm{ppm}),{ }^{[9]} \mathrm{L}^{*} \mathrm{GeNH}\left(2,6-i \mathrm{Pr}_{2} \mathrm{C}_{6} \mathrm{H}_{3}\right) \quad(\delta=4.85 \mathrm{ppm}),{ }^{[10]}$ and the gallium(III) amide $\mathrm{LGa}(\mathrm{NHPh})_{2} \quad(\delta=$ $6.16 \mathrm{ppm}){ }^{[23 \mathrm{~d}]}$

Compounds 1-3 form X-ray-suitable microcrystalline solids from solution in toluene and crystallize in the orthorhombic space group Pnma, whereas $\mathbf{4}$ crystallizes from hexane in the monoclinic space group $P 2_{1} / c$. The respective crystal data and collection parameters are listed in Table 1. The molecular structure of $\mathbf{1}$ (Figure 1), $\mathbf{2}$ (Figure 2), 3
(Figure 3), and 4 (Figure 4) show a three-coordinate germanium(II) center with two $\mathrm{Ge}-\mathrm{N}_{\text {ligand }}$ bond lengths (endo) and one $\mathrm{Ge}-\mathrm{N}_{\text {amide }}$ bond length (exo). For these compounds, the coordination geometry about germanium is derived from a distorted tetrahedron. The asymmetric unit of 1-3 has a mirror plane that passes through $\mathrm{C} 2, \mathrm{Ge} 1$, and the phenyl or pyridine ring; this parameter for $\mathbf{4}$ is a complete molecule.

Equivalent $\mathrm{Ge}-\mathrm{N}_{\text {ligand }}$ bond lengths are 1.9971(10), 1.9835(11), and 1.9914(12) $\AA$ for 1, 2 and 3, respectively; in 4 these nonequivalent bond lengths are 1.9935(13) and 2.0046(13) $\AA$, which are consistent with the analogous bond lengths of $\mathrm{LGeN}\left(\mathrm{C}_{6} \mathrm{~F}_{5}\right)_{2}$ [avg. 1.988(2) $\AA$ ] , ${ }^{[11]} \operatorname{LGeNH}(2,6$ $\left.i \mathrm{Pr}_{2} \mathrm{C}_{6} \mathrm{H}_{3}\right) \quad(\operatorname{avg} . \quad 2.038 \AA),{ }^{[9]} \quad \mathrm{LGeNH}_{2} \quad$ [2.030(2) $\left.\mathrm{A}\right],{ }^{[6]}$ $\mathrm{L} * \mathrm{GeNH}\left(2,6-i \mathrm{Pr}_{2} \mathrm{C}_{6} \mathrm{H}_{3}\right) \quad$ [avg. 2.0170(11) $\left.\mathrm{A}\right],{ }^{[10]}$ and $\mathrm{LGeNMe}_{2}[2.0309(16) \AA]^{[12]}$ and are slightly longer than the $\mathrm{Ge}-\mathrm{N}_{\text {ligand }}$ bond length of azide $\mathrm{L}^{\prime} \mathrm{GeN}_{3}[1.974(4) \AA] .^{[23]}$ Also, Ge-N $\mathrm{N}_{\text {amide }}$ bond lengths for 1 [1.8954(16) A], 2

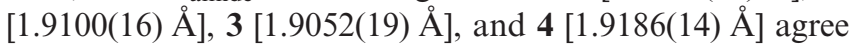
well with the $\mathrm{Ge}-\mathrm{N}_{\text {exo }}$ bond lengths of $\operatorname{LGeNH}(2,6$ $\left.i \mathrm{Pr}_{2} \mathrm{C}_{6} \mathrm{H}_{3}\right) \quad[1.906(2) \AA],{ }^{[9]} \quad \mathrm{L} * \mathrm{GeNH}\left(2,6-i \mathrm{Pr}_{2} \mathrm{C}_{6} \mathrm{H}_{3}\right)$ $[1.9097(12) \AA],{ }^{[10]}$ and $\mathrm{LGeNHNH}_{2}$ [1.909(5) $\left.\AA\right],{ }^{[12]}$ but they are slightly longer than bond lengths of $\mathrm{LGeNH}_{2}$ $[1.845(2) \AA]^{[6]}$ and $\mathrm{LGeNMe}_{2}(1.8712(14) \AA] .{ }^{[12]}$ In addition, they are slightly shorter than the $\mathrm{Ge}-\mathrm{N}_{\text {exo }}$ bond

Table 1. Crystal data and structure refinement details for compounds 1-4.

\begin{tabular}{|c|c|c|c|c|}
\hline & 1 & 2 & 3 & 4 \\
\hline Empirical formula & $\mathrm{C}_{29} \mathrm{H}_{35} \mathrm{GeN}_{3}$ & $\mathrm{C}_{28} \mathrm{H}_{34} \mathrm{GeN}_{4}$ & $\mathrm{C}_{28} \mathrm{H}_{34} \mathrm{GeN}_{4}$ & $\mathrm{C}_{34} \mathrm{H}_{46} \mathrm{GeN}_{4}$ \\
\hline$M_{\mathrm{r}}$ & 498.19 & 499.18 & 499.18 & 583.34 \\
\hline$T[\mathrm{~K}]$ & $100(2)$ & $100(2)$ & $100(2)$ & $100(2)$ \\
\hline$\lambda[\AA]$ & 0.71073 & 0.71073 & 0.71073 & 0.71073 \\
\hline Crystal system & orthorhombic & orthorhombic & orthorhombic & monoclinic \\
\hline Space group & Pnma & Pnma & Pnma & $P 2_{1} / c$ \\
\hline$a[\AA]$ & $14.1876(3)$ & $13.8592(11)$ & $14.1502(2)$ & $16.5066(6)$ \\
\hline$b[\AA]$ & $19.8449(5)$ & $20.0377(15)$ & $19.8948(5)$ & $8.7441(3)$ \\
\hline$c[\AA]$ & $9.1635(2)$ & $9.2178(7)$ & $8.9860(3)$ & $22.2179(6)$ \\
\hline$a\left[^{\circ}\right]$ & 90 & 90 & 90 & 90 \\
\hline$\beta\left[^{\circ}\right]$ & 90 & 90 & 90 & $96.937(2)$ \\
\hline$\gamma\left[^{\circ}\right]$ & 90 & 90 & 90 & 90 \\
\hline$V\left[\AA^{3}\right]$ & $2580.00(10)$ & $2559.8(3)$ & $2529.70(13)$ & $3183.35(18)$ \\
\hline$Z$ & 4 & 4 & 4 & 4 \\
\hline$D_{\text {calcd. }}\left[\mathrm{Mg} \mathrm{m}^{-3}\right]$ & 1.283 & 1.295 & 1.311 & 1.217 \\
\hline$\mu\left[\mathrm{mm}^{-1}\right]$ & 1.208 & 1.219 & 1.234 & 0.990 \\
\hline$F(000)$ & 1048 & 1048 & 1048 & 1240 \\
\hline Crystal size $\left[\mathrm{mm}^{3}\right]$ & $0.48 \times 0.25 \times 0.24$ & $0.35 \times 0.24 \times 0.14$ & $0.23 \times 0.15 \times 0.08$ & $0.28 \times 0.12 \times 0.10$ \\
\hline$\theta$ range $\left[{ }^{\circ}\right]$ & $2.05-27.50$ & $2.03-27.50$ & $2.05-27.50$ & $1.243-27.499$ \\
\hline \multirow[t]{3}{*}{ Index range } & $-18 \leq h \leq 18$ & $-18 \leq h \leq 11$ & $-18 \leq h \leq 14$ & $-15 \leq h \leq 21$ \\
\hline & $-24 \leq k \leq 25$ & $-25 \leq k \leq 16$ & $-25 \leq k \leq 25$ & $-11 \leq k \leq 11$ \\
\hline & $-11 \leq l \leq 11$ & $-11 \leq l \leq 11$ & $-11 \leq l \leq 9$ & $-28 \leq l \leq 28$ \\
\hline Reflections collected & 22563 & 12942 & 12738 & 29282 \\
\hline $\begin{array}{l}\text { Completeness }[\%] \text { to } \theta=27.50^{\circ}(\mathbf{1}-\mathbf{3}) \\
\theta=25.242^{\circ}(\mathbf{4})\end{array}$ & 100.0 & 99.7 & 100.0 & 100.0 \\
\hline Absorption correction & semiempirical & semiempirical & semiempirical & multiscan \\
\hline Max./min. transmission & $0.7602 / 0.5947$ & $0.8479 / 0.6749$ & $0.9078 / 0.7645$ & \\
\hline Refinement method & \multicolumn{4}{|c|}{ full-matrix least-squares on $F^{2}$ for all compounds } \\
\hline Data/restraints/parameters & $3046 / 0 / 167$ & $3007 / 0 / 167$ & $2995 / 0 / 167$ & $7321 / 0 / 366$ \\
\hline $\mathrm{GOF}^{[\mathrm{a}]}$ on $F^{2}$ & 1.076 & 1.068 & 1.035 & 1.012 \\
\hline$R$ indices $[I>2 \sigma(I)]^{[\mathrm{b}]}$ & $R_{1}=0.0219, w R 2=0.0604$ & $R_{1}=0.0229, w R 2=0.0600$ & $R_{1}=0.0252, w R 2=0.0629$ & $R_{1}=0.0296, w R 2=0.0654$ \\
\hline$R$ indices (all data) & $R_{1}=0.0232, w R 2=0.0609$ & $R_{1}=0.0266, w R 2=0.0618$ & $R_{1}=0.0303, w R 2=0.0650$ & $R_{1}=0.0414, w R 2=0.0698$ \\
\hline Largest diff. peak/hole $\left[\mathrm{e} \AA^{-3}\right]$ & $0.329 /-0.300$ & $0.378 /-0.269$ & $0.398 /-0.290$ & $0.385 /-0.306$ \\
\hline
\end{tabular}

[a] GOF $=\left[\Sigma \omega\left(F_{\mathrm{o}}^{2}-F_{\mathrm{c}}^{2}\right)^{2} /(n-p)\right]^{1 / 2} .[\mathrm{b}] R 1=\Sigma|| F_{\mathrm{o}}|-| F_{\mathrm{c}}|/ \Sigma| F_{\mathrm{o}} \mid, \omega R 2=\left[\Sigma \omega\left(F_{\mathrm{o}}^{2}-F_{\mathrm{c}}^{2}\right)^{2} / \Sigma \omega F_{\mathrm{o}}^{2}\right]^{1 / 2}$. 


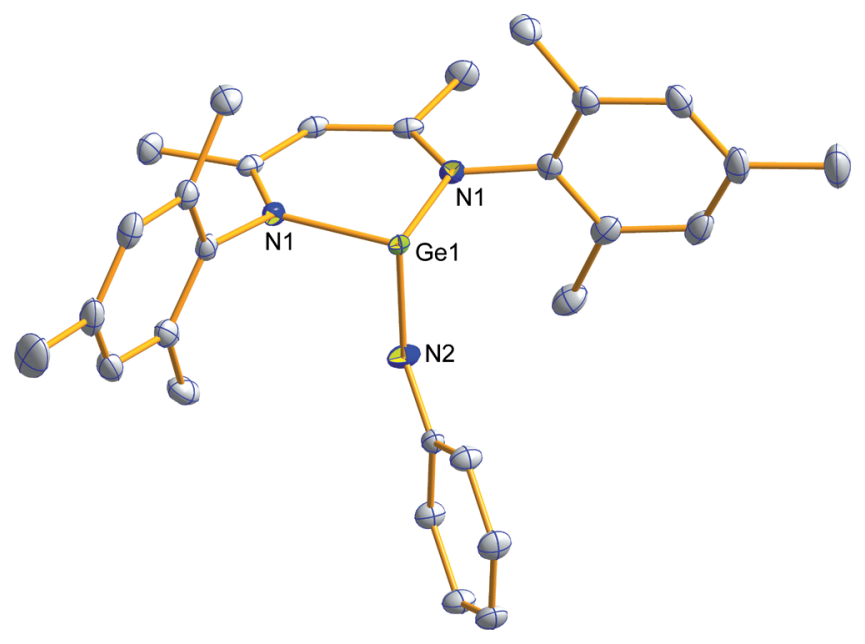

Figure 1. Molecular structure of $\mathbf{1}$. Anisotropic displacement parameters are depicted at $50 \%$ probability level, and all restrained refined hydrogen atoms are omitted for clarity. Selected bond lengths $[\AA]$ and angles $\left[^{\circ}\right]$ are Ge1-N2 1.8954(16), Ge1-N1 1.9971(10); N2-Ge1-N1 94.09(4), N1\#1-Ge1-N1 90.14(6).

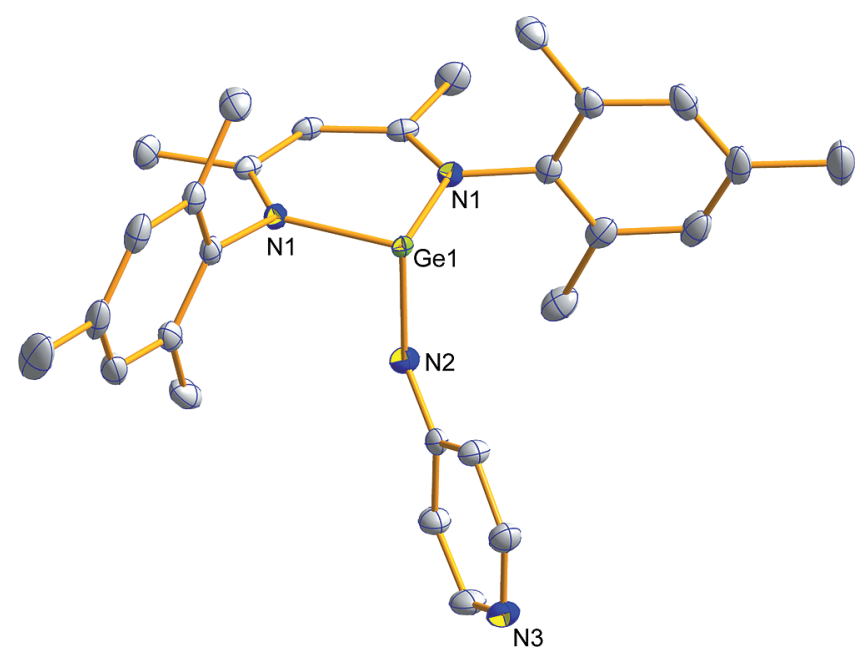

Figure 2. Molecular structure of 2. Anisotropic displacement parameters are depicted at $50 \%$ probability level, and all restrained refined hydrogen atoms are omitted for clarity. Selected bond lengths $[\AA]$ and angles $\left[{ }^{\circ}\right]$ are Ge1-N2 1.9100(16), Ge1-N1 1.9835(11); N2-Ge1-N1 94.69(5), N1-Ge1-N1\#1 90.95(6).

lengths of $\mathrm{L}^{\prime} \mathrm{GeN}_{3} \quad[1.979(5) \AA]^{[23]}$ and $\mathrm{LGeN}\left(\mathrm{C}_{6} \mathrm{~F}_{5}\right)_{2}$ $[2.054(2) \AA] \cdot{ }^{[11]}$

The bond angles around the germanium atom in complexes 1-4 are within the values reported for $\beta$-diketiminato germylene amides such as $\operatorname{LGeNH}\left(2,6-i \mathrm{Pr}_{2} \mathrm{C}_{6} \mathrm{H}_{3}\right),{ }^{[9]}$ $\mathrm{L}^{*} \mathrm{GeNH}\left(2,6-i \mathrm{Pr}_{2} \mathrm{C}_{6} \mathrm{H}_{3}\right),{ }^{[10]} \mathrm{LGeNH}_{2},{ }^{[6]} \mathrm{LGeN}\left(\mathrm{C}_{6} \mathrm{~F}_{5}\right)_{2},{ }^{[11]}$ and $\mathrm{LGeNMe}_{2}{ }^{[12]}$ The bond angles between the germanium atom and ligand nitrogen atoms (N1\#1-Ge1-N1) of $\mathbf{1}, \mathbf{2}$, and $\mathbf{3}$ are $90.14(6), 90.95(6)$, and $90.23(7)^{\circ}$, respectively, and are slightly shorter than the bond angle (N2Ge1-N1) for $4\left[89.00(5)^{\circ}\right]$. Moreover, the equivalent bond angles between the $\mathrm{N}_{\text {amide }}$ atom, germanium atom, and nitrogen ligand atoms (N1\#1-Ge1-N2 and N1-Ge1-N2) of 1, 2, and 3, [94.09(4), 94.69(5), and 94.52(5) ${ }^{\circ}$, respectively] compare well with $4, \mathrm{~N} 2-\mathrm{Ge} 1-\mathrm{N} 395.33(6)^{\circ}$; but the other

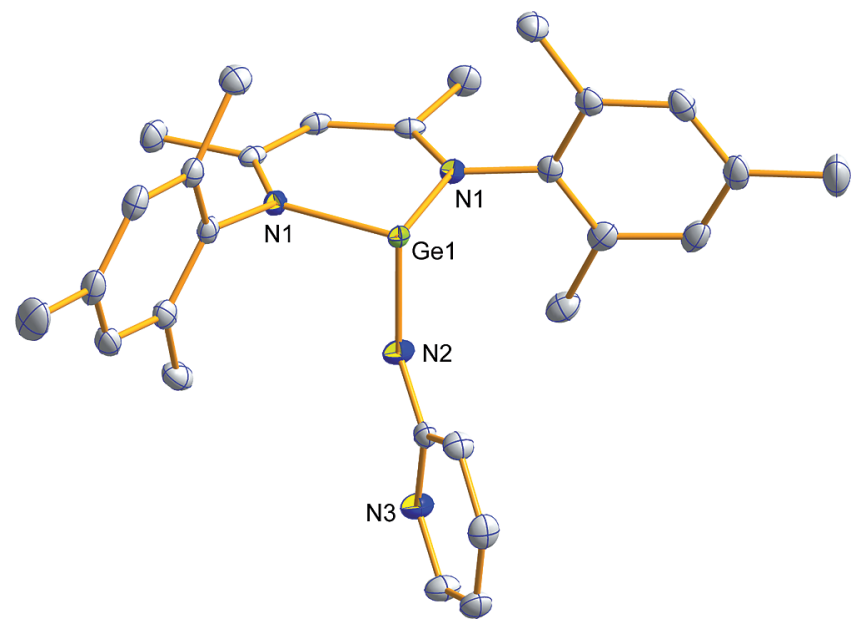

Figure 3. Molecular structure of 3. Anisotropic displacement parameters are depicted at $50 \%$ probability level, and all restrained refined hydrogen atoms are omitted for clarity. Selected bond lengths $[\AA]$ and angles $\left[{ }^{\circ}\right]$ are Ge1-N2 1.9052(19), Ge1-N1 1.9914(12); N2-Ge1-N1 94.52(5), N1-Ge1-N1\#1 90.23(7).

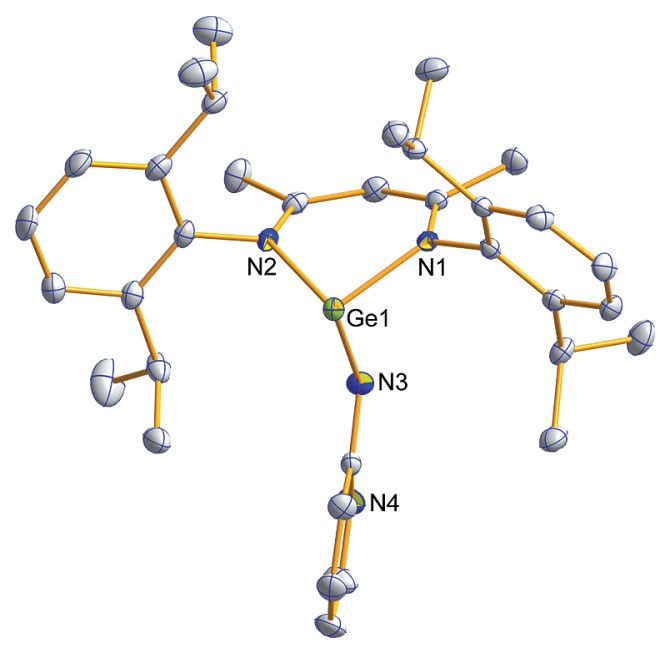

Figure 4. Molecular structure of 4. Anisotropic displacement parameters are depicted at $50 \%$ probability level, and all restrained refined hydrogen atoms are omitted for clarity. Selected bond lengths $[\AA]$ and angles $\left[{ }^{\circ}\right]$ are Ge1-N2 1.9935(13), Ge1-N1 2.0046(13), Ge1-N3 1.9186(14); N3-Ge1-N2 95.33(6), N3-Ge1N1 92.11(6), N2-Ge1-N1 89.00.

fragment is slightly longer, N1-Ge1-N3 $92.11(6)^{\circ}$. In fact, the tetrahedral geometry around the germanium atom in $\mathbf{4}$ has larger distortion than that of $\mathbf{1} \mathbf{- 3}$, probably as a result of ligand steric constraints.

Complexes 1-4 were also characterized by TGA to assess their thermal robustness and decomposition behavior that result from the substituent groups on the phenyl ring of the $\beta$-diketiminato ligand and the bonding of the amide fragment. TGA curves of 1-3 (Figure 5) show a slight mass loss about $150-200{ }^{\circ} \mathrm{C}$, which further decreases to reach a plateau at approximately $600{ }^{\circ} \mathrm{C}$, thus indicating a thermal decomposition. In the case of $\mathbf{4}$, the onset of thermal decomposition is $130-200^{\circ} \mathrm{C}$, but it further declines significantly at a lower temperature relative to $\mathbf{1 - 3}$. 


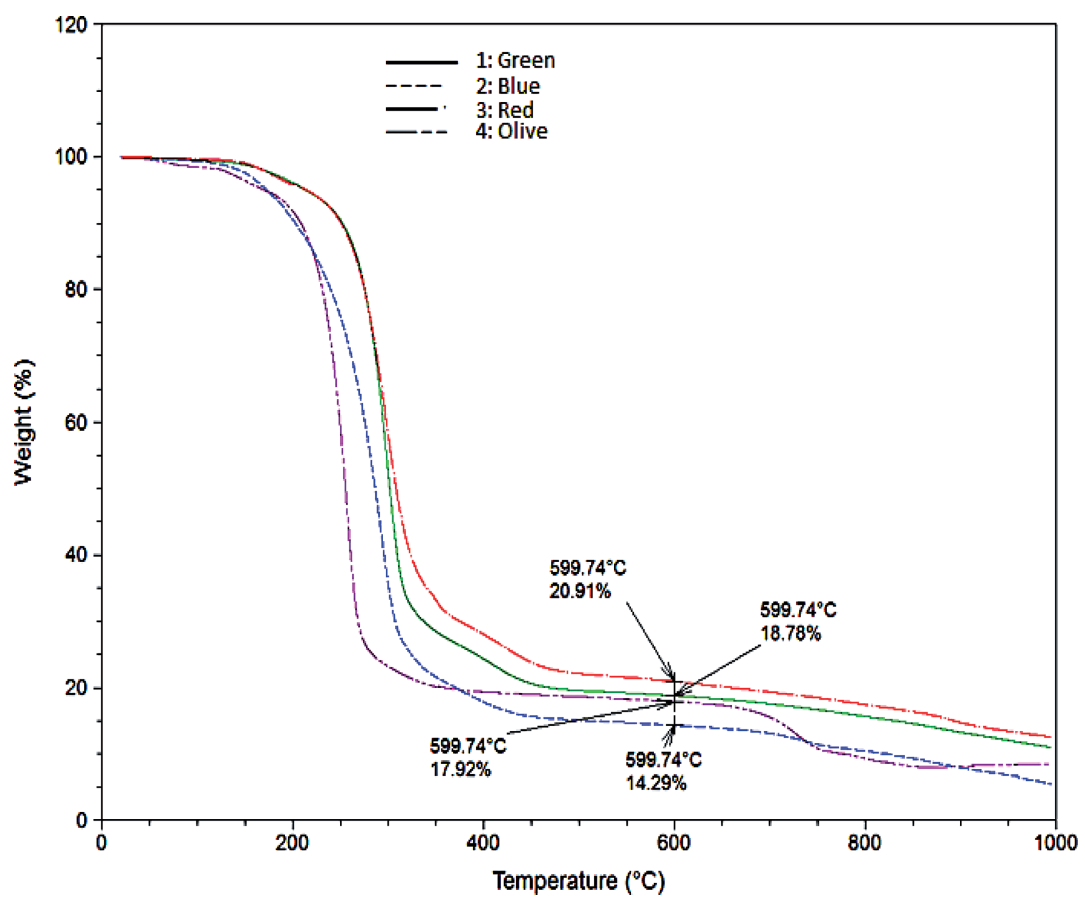

Figure 5. TGA data for compounds $\mathbf{1}-\mathbf{4}$.

Furthermore, $\mathbf{4}$ was chosen to verify the occurrence of a sublimation or decomposition process during the weight loss at about $130-200{ }^{\circ} \mathrm{C}^{[21]}$ The temperature of the sublimation apparatus was set to $140{ }^{\circ} \mathrm{C}$ and kept under vacuum $\left(10^{-2}\right.$ Torr $)$, with the collection of a white solid after $2 \mathrm{~h}$. No signals of compound 4 were detected in the ${ }^{1} \mathrm{H}$ NMR spectrum. Instead free-ligand signals and traces of unidentified products were observed, thus confirming its thermal decomposition at $140{ }^{\circ} \mathrm{C}$. It is probable that the bulkier nature of the isopropyl aromatic substituents on the ligand relative to the less sterically hindered methyl groups on ligands 1-3 eases the cleavage of $\mathrm{Ge}-\mathrm{N}_{\text {ligand }}$ fragment as temperature increases. In fact, the bite angle in $\mathbf{4}$ is more acute $\left[89.00(5)^{\circ}\right]$ than analogous angles for $\mathbf{1}-\mathbf{3}$. Indeed, these findings could be of interest if one assumes the formation of germanium nitride $\left(\mathrm{GeN}_{x}\right)$ as the stable product from the decomposition of 1-4 (Figure 5, residual mass at $600^{\circ} \mathrm{C}$ ).

\section{Conclusion}

In summary, a facile preparation of germylene amides supported by $\beta$-diketiminato ligands was demonstrated. In fact, spectroscopic and metrical data for 1-4 confirm the chemical composition in which the geometry at the germanium atom is a distorted tetrahedron, which denotes both ligand bulkiness and an amide fragment affect. According to TGA, compounds $\mathbf{1 - 4}$ all thermally decompose to form $\mathrm{GeN}_{x}$ rather than subliming intact, with the $\mathrm{Ge}-\mathrm{N}_{\text {ligand }}$ bond of $\mathbf{4}$ being cleaved more easily, presumably on account of greater ligand bulkiness. Future work in this area will focus on the synthesis of compounds bearing transitionmetal fragments [e.g., $\mathrm{Cu}_{2} \mathrm{R}_{4}(\mathrm{THF})_{2}$ ] coordinated to the nitrogen of the pyridine fragment in compounds $\mathbf{2}-\mathbf{4}$.

\section{Experimental Section}

General Methods: All manipulations were carried out using standard Schlenk and glovebox techniques under a dry atmosphere of nitrogen. The compounds $\mathrm{LGeCl}^{[2]}$ and $\mathrm{L}^{\prime} \mathrm{GeCl}^{[25]}$ were prepared by variations on the literature procedures, and aniline was distilled from potassium hydroxide under vacuum before use. Toluene and $\mathrm{C}_{6} \mathrm{D}_{6}$ were dried with the sodium benzophenone mixture; tetrahydrofuran and diethyl ether were dried with MBraun Solvent Purification Systems (MB-SPS). Dry hexane (95\%), methyllithium (1.6 $\mathrm{M}$ in $\mathrm{Et}_{2} \mathrm{O}$ ), 4-aminopyridine, and 2-aminopyridine were used as received from Aldrich. ${ }^{1} \mathrm{H}$ and ${ }^{13} \mathrm{C}$ NMR spectra were recorded with a Bruker $400 \mathrm{MHz}$ spectrometer and were referenced to the resonances of the solvent used. IR spectra were recorded with a Perkin-Elmer Spectrum 1000FT spectrometer as Nujol mulls between $\mathrm{NaCl}$ plates. Elemental analysis measurements were carried out by Atlantic Microlab Inc. Melting points were determined in sealed glass capillaries under nitrogen. TGA experiments were performed with a TA Instruments SDT 2960 using a $4{ }^{\circ} \mathrm{Cmin}^{-1}$ temperature ramp and $100 \mathrm{~mL} \mathrm{~min}^{-1}$ dry nitrogen flux.

General Preparation of $\mathrm{L}^{\prime} \mathrm{Ge}(\mathrm{NHPh})$ (1), $\mathrm{L}^{\prime} \mathrm{Ge}(4-\mathrm{NHPy})$ (2), and L'Ge(2-NHPy) (3): Methyllithium (1.6 M, $1.82 \mathrm{~mL}, 2.9 \mathrm{mmol}$ ) was added to a solution of the respective aromatic amine $(0.27 \mathrm{~g}$, $2.9 \mathrm{mmol})$ in $\mathrm{THF}(50 \mathrm{~mL})$ at $-78{ }^{\circ} \mathrm{C}$, whereupon the reaction mixture was warmed to room temperature and stirred for $0.5 \mathrm{~h}$. A solution of $\mathrm{L}^{\prime} \mathrm{GeCl}(1.29 \mathrm{~g}, 2.9 \mathrm{mmol})$ in THF $(50 \mathrm{~mL})$ was transferred by cannula to a precooled $\left(-78^{\circ} \mathrm{C}\right)$ mixture that contained the amine lithium salt. The reaction mixture was warmed to room temperature and stirred for $5 \mathrm{~h}$. All volatiles were subsequently removed under vacuum. The residue was extracted into toluene ( $80 \mathrm{~mL}$ for $\mathbf{2}$ and $60 \mathrm{~mL}$ for $\mathbf{1}$ and 3), filtered through Celite, and the resultant solution was slowly concentrated under vacuum until reaching the minimal volume of saturation.

Compound 1: Blocklike microcrystals were obtained from a saturated solution in toluene at $5^{\circ} \mathrm{C}$ after $2 \mathrm{~h}$, yield $62 \%(0.90 \mathrm{~g}$, $1.8 \mathrm{mmol})$, m.p. $205-208^{\circ} \mathrm{C} .{ }^{1} \mathrm{H}$ NMR (400 MHz, $\left.\mathrm{C}_{6} \mathrm{D}_{6}, 298 \mathrm{~K}\right): \delta$ 
$=1.55\left(\mathrm{~s}, 6 \mathrm{H}, \mathrm{NCCH}_{3}\right), 2.08,2.21,2.28\left(3 \mathrm{~s}, 3 \times 6 \mathrm{H}, o-\mathrm{CH}_{3}, p-\right.$ $\mathrm{CH}_{3}$ ), 4.91 (s, $\left.1 \mathrm{H}, \mathrm{NCCHCN}\right), 5.00$ (br. s, $1 \mathrm{H}, \mathrm{NH}$ ), 6.63 (t, $1 \mathrm{H}$, $p$ - $\mathrm{Ph}-H), 6.67,6.75(2 \mathrm{~s}, 2 \times 2 \mathrm{H}, m-\mathrm{Ar}-H), 6.79(\mathrm{~d}, 2 \mathrm{H}, o-\mathrm{Ph}-H)$, 7.07 (t, $2 \mathrm{H}, m-\mathrm{Ph}-H)$ ppm. ${ }^{13} \mathrm{C}$ NMR $\left(100 \mathrm{MHz}, \mathrm{C}_{6} \mathrm{D}_{6}, 298 \mathrm{~K}\right)$ : $\delta=19.20,19.27,20.80\left(o-\mathrm{CH}_{3}, p-\mathrm{CH}_{3}\right), 22.54\left(\mathrm{NCCH}_{3}\right), 96.48$ (NCCHCN), 115.76 ( $p$-C of $\mathrm{Ph}), 115.92$ ( $i-\mathrm{C}$ of $\mathrm{Ph}), 129.45,129.53$, $130.24,132.65,134.80,135.69,141.57,151.63(o-, m-C$ of $\mathrm{Ph}$ and $i-, o-, m-, p-C$ of Ar), $163.56(C=N)$ ppm. FTIR (Nujol): $\tilde{v}=3377$ (w, N-H) $\mathrm{cm}^{-1} . \mathrm{C}_{29} \mathrm{H}_{35} \mathrm{GeN}_{3}$ (498.21): calcd. 69.9, H 7.1, N 8.4; found C 67.9, H 6.9, N 8.1.

Compound 2: Blocklike microcrystals were obtained from a saturated solution in toluene at room temperature after $10 \mathrm{~h}$, yield $68 \%$ (0.99 g, $2.0 \mathrm{mmol})$, m.p. $243-245^{\circ} \mathrm{C} .{ }^{1} \mathrm{H}$ NMR (400 MHz, $\mathrm{C}_{6} \mathrm{D}_{6}$, $298 \mathrm{~K}): \delta=1.50\left(\mathrm{~s}, 6 \mathrm{H}, \mathrm{NCCH}_{3}\right), 2.07,2.15,2.16(3 \mathrm{~s}, 3 \times 6 \mathrm{H}, o-$ $\mathrm{CH}_{3}, p-\mathrm{CH}_{3}$ ), 4.88 (s, $1 \mathrm{H}, \mathrm{NCCHCN}$ ), 5.08 (br. s, $1 \mathrm{H}, \mathrm{NH}$ ), 6.44 $(\mathrm{d}, 2 \mathrm{H}, \alpha-\mathrm{Py}-H), 6.68,6.74(2 \mathrm{~s}, 2 \times 2 \mathrm{H}, m-\mathrm{Ar}-H), 8.32$ (d, $2 \mathrm{H}$, $\beta$-Py- $H$ ) ppm. ${ }^{13} \mathrm{C}$ NMR $\left(100 \mathrm{MHz}, \mathrm{C}_{6} \mathrm{D}_{6}, 298 \mathrm{~K}\right): \delta=18.95$, 19.19, $20.78\left(o-\mathrm{CH}_{3}, p-\mathrm{CH}_{3}\right), 22.47\left(\mathrm{NCCH}_{3}\right), 96.88(\mathrm{NCCHCN})$, 110.95 ( $\gamma$-C of Py), 129.56, 130.33, 132.58, 134.58, 136.09, 141.10, $150.89,157.18(\alpha-, \beta-C$ of Py and $i-, o-, m-, p-C$ of Ar), 164.08 $(C=N)$ ppm. FTIR (Nujol): $\tilde{v}=3321(\mathrm{vw}, \mathrm{N}-\mathrm{H}) \mathrm{cm}^{-1} \cdot \mathrm{C}_{28} \mathrm{H}_{34} \mathrm{GeN}_{4}$ (499.19): calcd. C 67.4, H 6.9, N 11.2; found C 65.3, H 7.0, N 10.3.

Compound 3: Blocklike microcrystals were obtained from a saturated solution in toluene at $5^{\circ} \mathrm{C}$ after $4 \mathrm{~d}$, yield $51 \%(0.75 \mathrm{~g}$, $1.5 \mathrm{mmol})$, m.p. $208-209^{\circ} \mathrm{C} .{ }^{1} \mathrm{H}$ NMR (400 MHz, $\left.\mathrm{C}_{6} \mathrm{D}_{6}, 298 \mathrm{~K}\right): \delta$ $=1.52\left(\mathrm{~s}, 6 \mathrm{H}, \mathrm{NCCH}_{3}\right), 2.07,2.18,2.33\left(3 \mathrm{~s}, 3 \times 6 \mathrm{H}, o-\mathrm{CH}_{3}, p-\right.$ $\mathrm{CH}_{3}$ ), 4.84 (s, $\left.1 \mathrm{H}, \mathrm{NCCHCN}\right), 6.13$ (br. s, $\left.1 \mathrm{H}, \mathrm{NH}\right), 6.26$ (t, $1 \mathrm{H}$, 5-Py-H), 6.61 (d, 1 H, 3-Py-H), 6.77, $6.81(2 \mathrm{~s}, 2 \times 2 \mathrm{H}, m-\mathrm{Ar}-H)$, $6.93(\mathrm{~m}, 1 \mathrm{H}, 4-\mathrm{Py}-H), 8.21$ (d, $1 \mathrm{H}, 6-\mathrm{Py}-H) \mathrm{ppm} .{ }^{13} \mathrm{C} \mathrm{NMR}$ $\left(100 \mathrm{MHz}, \mathrm{C}_{6} \mathrm{D}_{6}, 298 \mathrm{~K}\right): \delta=19.25,19.36,20.80\left(o-\mathrm{CH}_{3}, p-\mathrm{CH}_{3}\right)$, $22.48\left(\mathrm{NCCH}_{3}\right), 96.99$ ( $\left.\mathrm{NCCHCN}\right), 108.45,111.47,129.41,130.26$, 132.66, 134.91, 135.70, 136.66, 141.54, 149.19 (3-, 4-, 5-, 6- $C$ of Py and $i-, o-, m-, p-C$ of Ar), 163.29 (2- $C$ of Py), $163.67(C=N)$ ppm. FTIR (Nujol): $\tilde{v}=3365$ (w, N-H) $\mathrm{cm}^{-1} \cdot \mathrm{C}_{28} \mathrm{H}_{34} \mathrm{GeN}_{4}$ (499.19): calcd. C 67.4, H 6.9, N 11.2; found C 66.7, H 6.8, N 11.0.

Preparation of LGe(2NHPy) (4): Methyllithium $1.6 \mathrm{M}(1.9 \mathrm{~mL}$, $3.0 \mathrm{mmol})$ was added to a solution of 2-aminopyridine $(0.28 \mathrm{~g}$, $3.0 \mathrm{mmol})$ in $\mathrm{THF}(50 \mathrm{~mL})$ at $-78^{\circ} \mathrm{C}$, and the reaction mixture was warmed to room temperature and stirred for $0.5 \mathrm{~h}$. A solution of $\mathrm{LGeCl}(1.58 \mathrm{~g}, 3.0 \mathrm{mmol})$ in THF $(50 \mathrm{~mL})$ was transferred by cannula to a precooled $\left(-78{ }^{\circ} \mathrm{C}\right)$ mixture of the amine lithium salt. The reaction mixture was warmed to room temperature and stirred for $1 \mathrm{~h}$. All volatiles were subsequently removed under vacuum. The residue was extracted into hexane $(50 \mathrm{~mL})$, filtered through Celite, and the resultant solution was slowly concentrated under vacuum until all solvent was removed. The resultant product was a highpurity yellow solid, yield $86 \%(1.52 \mathrm{~g}, 2.6 \mathrm{mmol})$. Microcrystals were obtained from a saturated solution in hexane at room temperature after $3 \mathrm{~d}$, m.p. $168-170{ }^{\circ} \mathrm{C} .{ }^{1} \mathrm{H}$ NMR $\left(400 \mathrm{MHz}, \mathrm{C}_{6} \mathrm{D}_{6}\right.$, $298 \mathrm{~K}): \delta=1.02,1.09,1.17,1.32\left(4 \mathrm{~d}, 4 \times 6 \mathrm{H}, \mathrm{CHCH}_{3} \mathrm{CH}_{3}\right), 1.54$ $\left(\mathrm{s}, 6 \mathrm{H}, \mathrm{NCCH}_{3}\right), 3.36,3.55\left(2 \mathrm{~m}, 2 \times 2 \mathrm{H}, \mathrm{CHCH}_{3} \mathrm{CH}_{3}\right), 4.73$ (s, 1 $\mathrm{H}, \mathrm{NCCHCN}), 6.06$ (br. s, $1 \mathrm{H}, \mathrm{NH}), 6.22$ (t, $1 \mathrm{H}, 5-\mathrm{Py}-H), 6.48$ (d, 1 H, 3-Py-H), 6.85 (d, 1 H, 4-Py-H), 7.09 (m, $6 \mathrm{H}, m-\mathrm{Ar}-H, p-$ $\mathrm{Ar}-H), 8.12$ (d, $1 \mathrm{H}, 6-\mathrm{Py}-H) \mathrm{ppm} .{ }^{13} \mathrm{C} \mathrm{NMR}\left(100 \mathrm{MHz}, \mathrm{C}_{6} \mathrm{D}_{6}\right.$, $298 \mathrm{~K}): \delta=23.37\left(\mathrm{NCCH}_{3}\right), 24.10,24.58,24.64,26.42,28.84,29.29$ $\left(\mathrm{CHCH}_{3} \mathrm{CH}_{3}\right), 97.14(\mathrm{NCCHCN}), 108.98,111.41,124.14,125.02$, 127.61, 136.28, 141.13, 143.53, 146.47, 148.79 (3-, 4-, 5-, 6- $C$ of Py and $i-, o-, m-, p-C$ of Ar), 164.02 (2- $C$ of Py), $164.30(C=N)$ ppm. FTIR (Nujol): $\tilde{v}=3348(\mathrm{w}, \mathrm{N}-\mathrm{H}) \mathrm{cm}^{-1} \cdot \mathrm{C}_{34} \mathrm{H}_{46} \mathrm{GeN}_{4}$ (583.35): calcd. C 70.0, H 8.0, N 9.6; found C 68.8, H 8.0, N 9.2.

Structure Determination: Data for the structures of 1-4 were collected with a Bruker three-circle diffractometer equipped with a
APEX-II CCD detector with graphite-monochromated Mo- $K_{\alpha}$ radiation $(\lambda=0.71073 \AA$ ). Intensity measurements were performed on a rapidly cooled crystal using $\omega$ scans. Semiempirical absorption correction from equivalents implemented in the SADABS program was applied to the 1-4 dataset and led to satisfactory values for both $R_{\text {int }}$ and $R_{\sigma}{ }^{\left[{ }^{26]}\right.}$ Structures $\mathbf{1}-\mathbf{4}$ were solved by direct methods (SHELXS-97) $^{[27]}$ and refined with all data by full-matrix leastsquares methods on $F^{2}{ }^{[28]}$ The hydrogen atoms of $\mathrm{C}-\mathrm{H}$ bonds in compounds 1-4 were placed in idealized positions and refined isotropically with a riding model. The non-hydrogen atoms were refined anisotropically. Crystal data for compounds 1-4 are summarized in Table 1.

CCDC-950211 (for 1), -950213 (for 2), -950214 (for 3), and -1002250 (for 4) contain the supplementary crystallographic data for this paper. This data can be obtained free of charge from the Cambridge Crystallographic Data Centre via www.ccdc.cam. ac.uk./data_request/cif.

\section{Acknowledgments}

The authors are thankful to the Centro de Electroquímica y Energía Química (CELEQ), the Universidad de Costa Rica, and the Vice Presidency of Research, Universidad de Costa Rica (project number 804-B2-A59) for financial support. E. B.-M. acknowledges an Orlando Bravo CELEQ fellowship as well as CELEQ and Sistema de Estudios de Posgrado (SEP) of the Universidad de Costa Rica for providing complete financial support for an internship at Central Michigan University. Mr. Carlos Eduardo Solano Meza is thanked for sample preparation and the NMR Unit of the Escuela de Química at Universidad de Costa Rica for all their help.

[1] a) M. Asay, C. Jones, M. Driess, Chem. Rev. 2011, 111, 354 396; b) W. Levason, G. Reid, W. Zhang, Coord. Chem. Rev. 2011, 255, 1319-1341; c) S. Nagendran, H. W. Roesky, Organometallics 2008, 27, 457-492; d) W.-P. Leung, K.-W. Kan, K.-H. Chong, Coord. Chem. Rev. 2007, 251, 2253-2265; e) J. Barrau, G. Rima, Coord. Chem. Rev. 1998, 178-180, 593-622; f) J. Pfeiffer, W. Maringgele, M. Noltemeyer, A. Meller, Chem. Ber. 1989, 122, 245-252; g) A. Meller, G. Ossig, W. Maringgele, D. Stalke, R. Herbst-Irmer, S. Freitag, G. M. Sheldrick, J. Chem. Soc., Chem. Commun. 1991, 1123-1124.

[2] Y. Ding, H. W. Roesky, M. Noltemeyer, H.-G. Schmidt, P. P. Power, Organometallics 2001, 20, 1190-1194.

[3] Y. Ding, H. Hao, H. W. Roesky, M. Noltemeyer, H.-G. Schmidt, Organometallics 2001, 20, 4806-4811.

[4] L. W. Pineda, V. Jancik, H. W. Roesky, D. Neculai, A. M. Neculai, Angew. Chem. Int. Ed. 2004, 43, 1419-1421; Angew. Chem. 2004, 116, 1443.

[5] a) L. W. Pineda, V. Jancik, K. Starke, R. B. Oswald, H. W. Roesky, Angew. Chem. Int. Ed. 2006, 45, 2602-2605; Angew. Chem. 2006, 118, 2664; b) A. Jana, D. Ghoshal, H. W. Roesky, I. Objartel, G. Schwab, D. Stalke, J. Am. Chem. Soc. 2009, 131, $1288-1293$.

[6] A. Jana, I. Objartel, H. W. Roesky, D. Stalke, Inorg. Chem. 2009, 48, 798-800.

[7] A. Jana, H. W. Roesky, C. Schulzke, Dalton Trans. 2010, 39, $132-138$.

[8] L. Bourget-Merle, M. F. Lappert, J. R. Severn, Chem. Rev. 2002, 102, 3031-3065.

[9] W. Wang, S. Yao, C. van Wüllen, M. Driess, J. Am. Chem. Soc. 2008, 130, 9640-9641.

[10] W. D. Woodul, A. F. Richards, A. Stasch, M. Driess, C. Jones, Organometallics 2010, 29, 3655-3660.

[11] S. Yao, X. Zhang, Y. Xiong, H. Schwarz, M. Driess, Organometallics 2010, 29, 5353-5357. 
[12] A. Jana, H. W. Roesky, C. Schulzke, P. S. Samuel, A. Döring, Inorg. Chem. 2010, 49, 5554-5559.

[13] Y. Yang, N. Zhao, Y. Wu, H. Zhu, H. W. Roesky, Inorg. Chem. 2012, 51, 2425-2431.

[14] a) M. Driess, S. Yao, M. Brym, C. van Wüllen, Angew. Chem. 2006, 118, 4455-4458; b) M. Driess, S. Yao, M. Brym, C. van Wüllen, Angew. Chem. Int. Ed. 2006, 45, 4349-4352; Angew. Chem. 2006, 118, 4455.

[15] J. Clayden, N. Greeves, S. Warren, Organic Chemistry, 2nd. ed., Oxford University Press, Oxford, UK, 2012, p. 196-197.

[16] A. Akkari, J. J. Byrne, I. Saur, G. Rima, H. Gornitzka, J. Barrau, J. Organomet. Chem. 2001, 622, 190-198.

[17] D. D. Vaughn II, R. E. Schaak, Chem. Soc. Rev. 2013, 42, 2861-2879.

[18] C.-H. Kim, E.-S. Ha, H. Baik, K.-J. Kim, Chem. Asian J. 2011, 6, 850-855.

[19] S. Prabakar, A. Shiohara, S. Hanada, K. Fujioka, K. Yamamoto, R. D. Tilley, Chem. Mater. 2010, 22, 482-486.

[20] B. Fahlman, Materials Chemistry, 2nd ed., Springer, New York, 2011, p. 255-320.

[21] P. L. Franceschini, M. Morstein, H. Berke, H. W. Schmalle, Inorg. Chem. 2003, 42, 7273-7282.

[22] D. González-Flores, S. A. Patil, P. A. Medina, S. Dever, C. Uthaisar, L. W. Pineda, M. L. Montero, J. W. Ziller, B. D. Fahlman, Inorg. Chim. Acta 2013, 396, 60-65.

[23] a) N. D. R. Barnett, W. Clegg, L. Horsburgh, D. M. Lidsay, Q. Liu, F. M. Mackensie, R. E. Mulvey, P. G. Williard, Chem.
Commun. 1996, 20, 2321-2322; b) D. Barr, W. Clegg, L. Cowton, L. Horsburgh, F. M. Mackensie, R. E. Mulvey, J. Chem. Soc., Chem. Commun. 1995, 891-892; c) W. Clegg, D. T. Liddle, R. E. Mulvey, A. Robertson, Chem. Commun. 2000, 223-224; d) D. Solis-Ibarra, A. P. Gómora-Figueroa, N. Zavala-Segovia, V. Jancik, Eur. J. Inorg. Chem. 2009, 4564-4571; e) R. von Bülow, H. Gornitzka, T. Kottke, D. Stalke, J. Chem. Soc. Chem. Commun. 1996, 1639-1640. For some selected reviews on lithium amide ring-stacking and ring-laddering, see: f) K. Gregory, P. v. R. Schleyer, R. Snaith, Adv. Inorg. Chem. 1991, 37, 47-142; g) R. E. Mulvey, Chem. Soc. Rev. 1991, 20, 167-209; h) R. E. Mulvey, Chem. Soc. Rev. 1998, 27, 339-346.

[24] V. Jancik, L. W. Pineda, A. C. Stückl, H. W. Roesky, R. HerbstIrmer, Organometallics 2005, 24, 1511-1515.

[25] A. E. Ayers, T. M. Klapötke, H. V. Rasika Dias, Inorg. Chem. 2001, 40, 1000-1005.

[26] G. M. Sheldrick, SADABS, Program for Absorption Correction, University of Göttingen, Germany, 1997. Compound 1: $R_{\mathrm{int}}=$ $0.0176, R_{\sigma}=0.0102$; compound 2: $R_{\text {int }}=0.0187, R_{\sigma}=0.0161$; compound 3: $R_{\mathrm{int}}=0.0225, R_{\sigma}=0.0192$; compound 4: $R_{\mathrm{int}}=$ $0.0359, R_{\sigma}=0.0112$.

[27] SHELXS-97: G. M. Sheldrick, Acta Crystallogr., Sect. A 1990, $46,467-473$.

[28] G. M. Sheldrick, SHELXL-97, Program for Crystal Structure Refinement, University of Göttingen, Germany, 1997.

Received: June 25, 2014

Published Online: September 5, 2014 